\title{
Gender differences in Nociceptin/Orphanin FQ-induced food intake in strains derived from rats prone (WOKW) and resistant (Dark Agouti) to metabolic syndrome: a possible involvement of the cocaine- and amphetamine-regulated transcript system
}

\author{
Serena Battistoni • Ingrid Kloting • Carlo Cifani • \\ Maurizio Massi • Carlo Polidori
}

Received: 13 May 2010/Accepted: 9 October 2010/Published online: 13 November 2010

(C) Springer-Verlag 2010

\begin{abstract}
Our previous study found that when injected with Nociceptin/Orphanin FQ (N/OFQ) into the brain, male Dark Agouti (DA) rats, which are resistant to metabolic syndrome, have greater hyperphagia than male Wistar Ottawa Karlsburg W (WOKW) animals, which are prone to this disease. We attributed this difference to the fact that these two strains have different cocaine-amphetamine regulated transcript peptide (Cart) gene sequences and expression. In order to address this hypothesis, the present work focused on sex differences and analyzed not only male but also female N/OFQ-induced $(0.25$ and $0.5 \mathrm{nmol} /$ rat) food intake in terms of their Cart and N/OFQ receptor gene expression in the hypothalamic area. In N/OFQ-naive WOKW females, cart gene expression is extremely elevated compared to N/OFQ-naive WOKW males. When male and female WOKW littermates are stimulated with $\mathrm{N} / \mathrm{OFQ}$, the food intake of females is significantly lower than that of the males. Granted, the N/OFQ feeding behavior experiments were not performed on the animals measured for Cart gene expression, but nonetheless, the responses observed in littermates point to an interesting avenue for further inquiry.
\end{abstract}

Keywords Nociceptin/orphanin FQ - Dark Agouti rats . Wistar Ottawa Karlsburg W rats - Cocaine-amphetamine regulated transcript peptide $\cdot$ Congenic rats

\footnotetext{
I. Kloting

Department of Laboratory Animal Science, Medical Faculty, University of Greifswald, 17495 Karlsburg, Germany

S. Battistoni - C. Cifani - M. Massi - C. Polidori ( $\square)$ Department of Experimental Medicine and Public Health, University of Camerino, Via Madonna delle Carceri, 62032 Camerino, Italy

e-mail: carlo.polidori@unicam.it
}

\section{Introduction}

A number of studies have suggested that brain dysfunctions may be the underlying cause for the development of the metabolic syndrome $[8,12,18,24]$, which is characterized by obesity, hypertension, dyslipidemia, insulin resistance, and impaired glucose tolerance [1].

In addition, the N/OFQ system has been recently proven to be important in the development of obesity. A study in mice with continuous 2 week intracerebral infusion of N/OFQ provoked obesity-induced symptoms [11]. It has also been shown that N/OFQ contributes to the development of obesity not only by inducing hyperphagia but also by decreasing energy expenditure [11].

Our previous work demonstrated that Nociceptin/ Orphanin FQ (N/OFQ), the endogenous ligand for the NOP receptor, previously referred to as opioid receptorlike 1 receptor (ORL1) or OP4 receptor, injected into the lateral brain ventricle, had less hyperphagic effect in male WOKW rats than in male DA rats, whose food intake was comparable to that previously described for Wistar rats [19]. While we were conducting the above experiments, Bewick et al. [3] showed that N/OFQ at the hypothalamic level inhibits the release of the cocaineand amphetamine-regulated transcript (Cart) peptide. Drawing upon their results, we evaluated genetic expression of Cart in male WOKW animals and observed that there is a strong inverse correlation between N/OFQinduced feeding and gene expression in these rats. This might partially explain the difference in the hyperphagic effect of N/OFQ. Based on this work and our previous findings [21], our major hypothesis is that N/OFQ might induce hyperphagia by inhibiting the endogenous Cart peptide, which has an inhibitory effect on feeding behaviour [7]. 
Cart is highly expressed in areas involved in food intake such as arcuate nucleus, lateral hypothalamus, paraventricular nucleus and nucleus accumbens [5, 22].

In order to further understand the mechanism of action in N/OFQ-induced hyperphagia, in the present work we tested not only DA and WOKW males but also females and analyzed their N/OFQ-induced food intake in terms of their Cart and ORL1 gene expression in the hypothalamic area. As there is no existing data in the literature on female rats with metabolic syndrome regarding the hyperphagic action of N/OFQ, we wanted to investigate whether similarities or differences in feeding behavior responses in the males and females might confirm or refute the hypothesis of CART involvement in feeding behavior.

\section{Methods}

Animal housing and surgery

Males $(N=9)$ and females $(N=8)$ of DA $(>$ F80) and WOKW ( $N=10$ males and $N=7$ females) rats (F69), from the Department of Laboratory Animal Science of the University of Greifswald (Karlsburg, Germany), were individually housed in the animal facility of the Department of Experimental Medicine and Public Health of the University of Camerino in hanging polyacrylic cages with wood chip bedding in a room with an artificial 12:12 $\mathrm{h}$ light/dark cycle (dark onset at 9:00 p.m.) and a constant temperature of $20-22^{\circ} \mathrm{C}$. They were offered free access to regular chow pellets (Mucedola Diets, Settimo Milanese, Italy) in hoppers hung on the cage wall and to tap water ad libitum.

Rats were food deprived overnight and anesthetized by intramuscular injection of Tiletamine chlorahydrate (200 mg/kg) and Zolazepam chlorahydrate $(200 \mathrm{mg} / \mathrm{kg})$ (Laboratoires Virbac, Carros, France). A prophylactic dose of Rubrocillin $200 \mu \mathrm{l} /$ rat (Farmaceutici Gellini Spa, Aprilia, Italy) was also given by intramuscular injection. Then, a 22-gauge guide cannula for intracerebroventricular (ICV) injections was stereotaxically implanted into the third brain ventricle $(3 \mathrm{~V}): 1 \mathrm{~mm}$ posterior to the bregma, $1 \mathrm{~mm}$ lateral to the sagittal suture and $7 \mathrm{~mm}$ ventral to the surface of the skull with an angle of $10^{\circ}$. A stainless-steel obturator of the same length was placed into the guide cannula at the end of surgery. A 30-gauge injector that was $2.5 \mathrm{~mm}$ longer than the guide cannula was used for ICV injections. The volume injected into the $3 \mathrm{~V}$ was of $1 \mu \mathrm{l}$. Correct cannula implantation was verified by injecting Ang II $10 \mathrm{ng} / \mu \mathrm{l}$ into the third ventricle and measuring its dypsogenic effect. Only animals that drank at least $5 \mathrm{ml}$ of water in 15 min were selected for the experiments.
One week after intracranial surgery all the animals were ICV treated with saline to familiarize them with the ICV injection.

\section{Feeding studies}

Unfasted animals received ICV injection of N/OFQ (the doses of 0.25 and $0.5 \mathrm{nmol} / \mathrm{rat}$ were chosen on the basis of previous studies [19] on Wistar rats) or their vehicle (distilled water), into the third brain ventricle in a Latin square order. Each treatment occurred every 4 days at 9 a.m. Their food intake was measured 1,2 and $24 \mathrm{~h}$ after the ICV injection.

\section{Gene expression}

Hypothalamic regions were isolated and processed as previously described in a subset of animals which were not implanted with the ICV cannula. Gene expression analysis of the NOP receptor (Oprl1), and Cart peptide was conducted on males and females of each strain at an age of 4 weeks (DA 5 males and 6 females, WOKW 6 males and 8 females). At the time of euthanasia, the hypothalamus was removed. The total RNA of organs was isolated, transcribed in cDNA and used for real-time PCR as detailed before [6]. Each quantitative PCR was performed in duplicate. Target cDNA was amplified by primer sets of Oprl1 (GenBank acc. no.: NC_005102; forward 50-tgtatggcagccactttcaa-30 reverse 50-agtccaaggggcagga ag-30), Cart (GenBank acc. no.: NC_005101; forward 50-cctactgetgctgctacct-30 reverse 50-ttctcatgggacgcatcat30), and of Pnoc (Gen-Bank acc. no.: NM_013007; forward 50-ctctctggactctttgcacca-30 reverse 50-cgaggcttcgactggt aaa-30). The rat $18 \mathrm{~S}$ rRNA gene (eukaryotic $18 \mathrm{~S}$ rRNA endogenous control; FAMTM Dye/MGB Probe, Applied Biosystems) served as the endogenous reference gene. The standard curve method was used for relative quantification. For each experimental sample, the amount of targets and the endogenous reference, $18 \mathrm{~S}$ rRNA, were determined from the calibration curve. The target amount was then divided by the endogenous reference amount to obtain a normalized target value.

Statistical analysis

Statistical analysis was performed with the software Systat (Version 10). Analysis of variance (ANOVA) for feeding experiments considering sex and strain as between factors while treatment and time as within factors. ANOVA for gene expression experiments was performed considering strain and sex as between factors and gene expression as within factor. Post-hoc analysis was performed using the 
Bonferroni paired t-test. Statistical significance between groups was set at $P<0.05$.

\section{Results}

Feeding responses

The feeding response to N/OFQ stimulation occurs mostly in the first $2 \mathrm{~h}$ after its ICV injection. The overall ANOVA, considering male and female WOKW and DA food intake data altogether $(1,2$, and $24 \mathrm{~h})$, shows that there is no significant effect due to sex difference, but that there is one for the strain factor $\left(F_{\text {strain }}(1,36)=6.33 ; P<0.05\right)$. Strong effect was observed due to the treatment $\left(F_{\text {treat }}(2,72)=\right.$ $10.67 ; P<0.001)$ and the time $\left(F_{\text {time }}(2,72)=878.56\right.$; $P<0.001)$ and treatment-time interaction factors $\left(F_{\text {treat-time }}(4,144)=4.74 ; P<0.01\right)$. Finally, a significant treatment-strain effect was observed $\left(F_{\text {treat-strain }}(2,72)=\right.$ $3.51 ; P<0.05)$.

\section{Effect of $N / O F Q$ in DA rats}

The ANOVA test, considering only the food intake data of male and female DA rats, showed no sex difference within this strain in the total food intake for the entire $2 \mathrm{~h}$ (Fig. 1a) and $24 \mathrm{~h}$ post N/OFQ injection $\left[F_{\text {sex }}(1,17)=2.17\right.$; $P=0.159]$.

In accord with our previous study, in the first hour after ICV injection, there was a significant increase in food intake due to N/OFQ in DA male when compared to their vehicle treated $(P<0.05)$. In DA female rats injected with N/OFQ, there was also a significant effect of treatment and

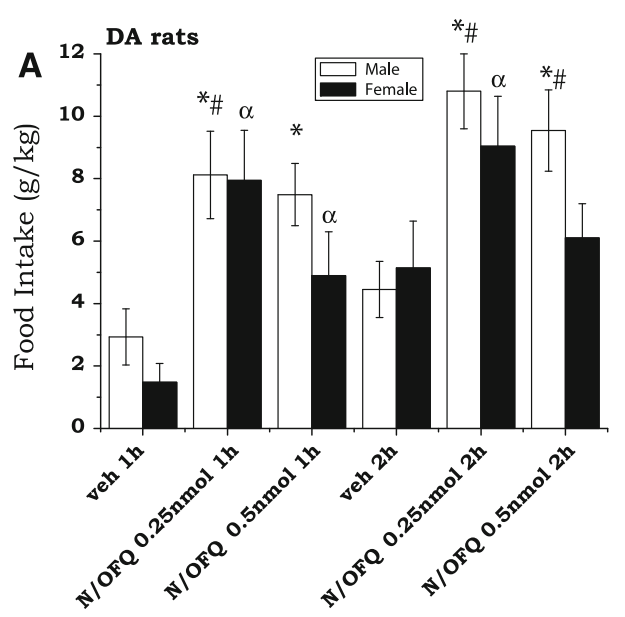

Fig. 11 and $2 \mathrm{~h}$ food intake $(\mathrm{g} / \mathrm{kg})$ in Dark Agouti male and female rats (a) and WOKW male and female rats (b) that received an injection into the third brain ventricle of N/OFQ (at doses of 0.25 and $0.5 \mathrm{nmol} / \mathrm{rat}$ ) or its vehicle in a Latin square order. Each bar represents the mean \pm SEM of several rats. Statistical difference time respectively when compared to their vehicle treated animals $\left(\left[F_{\text {treat }}(2,14)=4.57 ; \quad P<0.05\right] ; \quad\left[F_{\text {time }}(2,14)=\right.\right.$ 224.1; $P<0.001]$ ) (Fig. 1a).

\section{Effect of $N / O F Q$ in $W O K W$ rats}

Nociceptin/OFQ-treated WOKW male rats ate significantly more when compared to their vehicle treated animals $\left(\right.$ ANOVA: $\left[F_{\text {treat }}(2,26)=6.78 ; P<0.005\right] ;\left[F_{\text {time }}(2,26)=\right.$ 264.3; $P=0.001])$. The effect was significant only during the first $2 \mathrm{~h}(P<0.05)$ (Fig. 1b), while at $24 \mathrm{~h}$ there was no significant difference (Table 1). WOKW females did not increase their feeding behavior, compared to their vehicle treated ones, at any dose of N/OFQ administered (Fig. 1b).

\section{Gene expression}

Gene expressions for N/OFQ receptor (still called the Oprl1 receptor in the NCBI GenBank data base) and Cart peptide in DA and WOKW rats are shown in Table 2. The ANOVA revealed a significant difference in hypothalamic Oprl1 and Cart gene expression between the entire strain/ sex factor (considered as single factor for the four groups; DAm, DAf, WOKWm and WOKWf) $F_{\text {Oprl1 }}(3,21)=9.82$; $P<0.0001$ and $F_{\text {Cart }}(3,21)=225 ; P<0.0001$. The posthoc test showed a significant difference in hypothalamic Oprl1 gene expression between Dam and DAf, WOKWm and DAf, WOKWf and DAm and finally, between WOKWm and WOKWf. The post-hoc test showed a significant difference in hypothalamic Cart gene expression between DAm and WOKWm, Dam and WOKWf, WOKWm and DAf, WOKWm and WOKWf and finally WOKWf and DAf (Table 2).

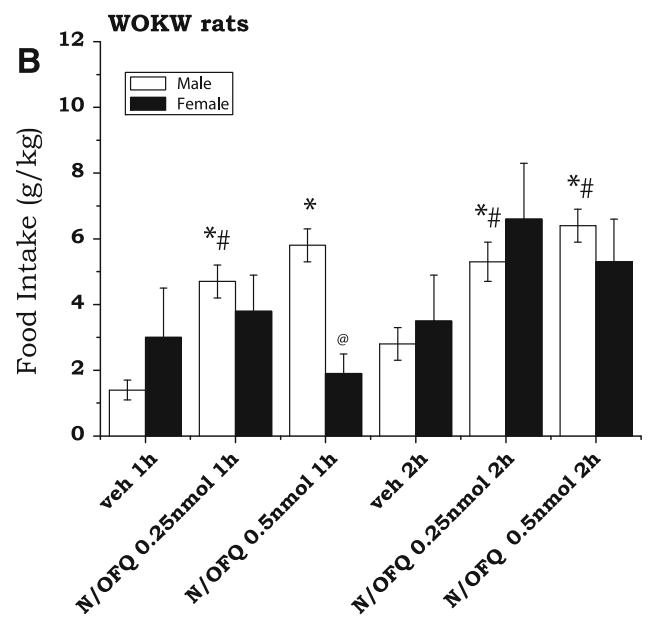

from controls: * difference from the vehicle of the same time in male rats; ${ }^{\alpha}$ difference from the vehicle of the same time in female rats; \# difference between treatments in male DA e WOKW rats; @ difference between WOKW male and female 
Table 1 Cumulative food intake $(\mathrm{g} / \mathrm{kg})$ in male and female DA and WOKW rats

\begin{tabular}{|c|c|c|c|c|}
\hline \multirow[t]{2}{*}{ Treatment } & \multicolumn{2}{|c|}{ DA food intake $(\mathrm{g} / \mathrm{kg})$} & \multicolumn{2}{|c|}{ WOKW food intake $(\mathrm{g} / \mathrm{kg})$} \\
\hline & Males & Females & Males & Females \\
\hline Vehicle $(24 \mathrm{~h})$ & $54.6 \pm 3.7$ & $51.3 \pm 3.8$ & $52.7 \pm 3.3$ & $48.1 \pm 3.1$ \\
\hline N/OFQ (24 h) $0.25 \mathrm{nmol}$ & $56.6 \pm 2.3$ & $53.4 \pm 3.2$ & $50.1 \pm 2.7$ & $47.3 \pm 4.1$ \\
\hline N/OFQ (24 h) $0.5 \mathrm{nmol}$ & $57.7 \pm 2.5$ & $52.1 \pm 2.7$ & $51.7 \pm 3.2$ & $48.4 \pm 2.9$ \\
\hline
\end{tabular}

Table 2 Oprl1 and Cart gene expression in DA and WOKW rats relative to 18S mRNA

\begin{tabular}{|c|c|c|c|c|}
\hline \multirow[t]{2}{*}{ Strain } & \multicolumn{2}{|l|}{ Oprl1 } & \multicolumn{2}{|l|}{ Cart } \\
\hline & Males & Females & Males & Females \\
\hline DA & $1.06 \pm 0.16^{\mathrm{a}}(N=5)$ & $1.55 \pm 0.33^{\mathrm{a} *}(N=6)$ & $1.22 \pm 0.11^{\mathrm{d}}(N=5)$ & $0.59 \pm 0.22(N=6)$ \\
\hline WOKW & $0.92 \pm 0.23^{\mathrm{b}}(N=6)$ & $1.51 \pm 0.23^{\mathrm{b} *}(N=8)$ & $4.95 \pm 0.69^{\mathrm{c}, \mathrm{d} *}(N=6)$ & $5.83 \pm 0.45^{\mathrm{c} *}(N=8)$ \\
\hline
\end{tabular}

${ }^{a}$ Oprl1 gene expression differs significantly between DA males and DA females $(* P<0.05)$

${ }^{\mathrm{b}}$ Oprl1 gene expression differs significantly between WOKW males and WOKW females $(P<0.005)$

${ }^{c}$ Cart gene expression differs significantly between WOKW males and WOKW females $(P<0.001)$

${ }^{\mathrm{d}}$ Cart gene expression differs significantly between DA males and WOKW males

\section{Discussion}

Our previous data described significant differences between N/OFQ-induced food intake in DA and WOKW male rats [4]. Our concluding hypothesis was that N/OFQinduced hyperphagia could be regulated by the Cart peptide. In the present study, in order to further explore this phenomenon, we extended inquiry to include female as well as male DA and WOKW rats, performing N/OFQ injections and analyzing their N/OFQ-induced food intake. We also looked at the Cart gene expression of their littermates. We observed significant differences in feeding behavior between DA and WOKW males, confirming data previously observed after injecting N/OFQ in the lateral ventricle. We also observed significant differences in N/OFQ-induced food intake between WOKW males and females after $1 \mathrm{~h}$ at a treatment of $0.5 \mathrm{nmol} / \mathrm{rat}$. Looking at the Cart gene expression of littermates that were not part of the N/OFQ feeding behavior experiments, we noted that WOKW females have high Cart gene expression compared to WOKW males, while DA males have lower expression than WOKW males. Taking into account these differences in Cart gene expression, we suggest that this may be the underlying mechanism for the differences observed in the feeding behavior; further studies should be done on the same animals, measuring feeding behavior and then Cart gene expression to explore this hypothesis.

Neither strain exhibited a hyperphagic dose-response. In fact, in DA females, the higher N/OFQ dose evoked a lower stimulation of food intake. This could be due to the well known inhibitory effect of N/OFQ on motor function [10].
The hypothesis of Cart involvement in N/OFQ-induced feeding is strengthened in this study by the Oprl1 and Cart gene expression data in female littermates of those used in the feeding behavior studies. Indeed, there is no significant difference between Oprl1 gene expression in DA females compared to WOKW females.

Recent inquiry into the mechanisms involved in feeding behavior has afforded interesting input regarding the mechanistic link between N/OFQ and Cart peptide. It is well known that $\mathrm{N} / \mathrm{OFQ}$, like many neuropeptides, is particularly concentrated in brain areas controlling food intake, such as the hypothalamus [2,14] and also in other areas [2] such as the arcuate nucleus, the LHA, the VTA, the dorsal raphe nucleus, and the PVN.

It is well known that N/OFQ is found in the arcuate nucleus and LHA, two important areas that control feeding behavior. Cart peptide and $\alpha$-melanocyte-stimulating hormone $(\alpha-\mathrm{MSH})$ are principally located in the ventrolateral part of the arcuate nucleus. A recent study observed that Cart-containing cell bodies of the arcuate nucleus are colocalised with N/OFQ and $\alpha-\mathrm{MSH}$ and suggested that N/OFQ, released together with $\alpha$-MSH and Cart, acts on presynaptic NOP autoreceptors to prevent the release of $\alpha$-MSH and/or Cart [9]. This idea is reinforced by the previous observation [3] that Cart neurones express the NOP1 receptor and that incubation of mediobasal hypothalamic explants with N/OFQ results in a decrease in the release of immunoreactive Cart. Since no significant change was observed in $\alpha-\mathrm{MSH}$ release, Bewick suggested that N/OFQ exerts a selective influence on Cart, and not on the $\alpha$-MSH release.

In addition to the possible mechanistic link between N/OFQ and Cart on the hypothalamic level, there may be 
similar activity in the VTA. It is known that N/OFQ influences dopamine neuronal activity, acting directly on mesolimbic dopamine neurons of the VTA [15]. Cart peptides have also been found to modulate mesolimbic dopamine, which could interfere with the rewarding and reinforcing properties of foods [5]. A possible modulation at the level of the VTA of N/OFQ on Cart peptide release could explain our effects on feeding behaviour.

A study of the role of the N/OFQ system in the regulation of food intake has shown that N/OFQ receptors are strongly activated in the dorsal raphe nucleus after $24 \mathrm{~h}$ food deprivation [20]. It is also well known that N/OFQ inhibits the release of serotonin in this nucleus [13], which, in our conditions may partially contribute to explain the hyperphagic effect induced by N/OFQ.

Another mechanistic link between Cart and N/OFQ may take place in the PVN, a brain area controlling food intake. Previous data from our group [21] have shown an increase in NOP receptors in the PVN in food deprived animals. In addition, it has been shown that direct injection of Cart into the PVN reduces food intake [23, 25]. The current study did injections into the third ventricle; since this ventricle bathes the PVN, our feeding response could be due to stimulation of NOP receptors in that nucleus.

The roles of the N/OFQ system and Cart peptide in food intake regulation have been explored in numerous works. A study that injected N/OFQ into the right lateral ventricle demonstrated that N/OFQ-induced food intake can be completely blocked by naloxone and cannabinoid $\mathrm{CB}_{1}$ receptor antagonist, either alone or together [17]. Interestingly, $\mathrm{CB}_{1}$ agonists increase Cart peptide levels in the nucleus accumbens [16]. Injection of Cart peptide into the nucleus accumbens has been shown to inhibit feeding, indicating that this region, which has high levels of endogenous Cart peptides, might be involved in the Cart system's anorexigenic effects [26]. These data, together with ours, may suggest that Cart might be the final step in N/OFQ induced hyperphagia and that $\mathrm{CB}_{1}$ and opioid receptors might be intermediary steps.

In conclusion, our findings on the mechanism by which N/OFQ participates in the regulation of food intake and energy balance may contribute to developing pharmacological tools to intervene in the reduction/increase of food intake and in the control of obesity/anorexia. Cart agonists and/or antagonists have yet to be discovered, but once available should be highly useful for future studies to validate our findings.

Acknowledgments The present research was financed by the Italian Ministry of Education, University and Research (MIUR, COFIN 2006) funds awarded to the team of Professor Maurizio Massi. We would also like to thank Sheila Beatty for linguistic revision of this manuscript.

\section{References}

1. Alberti KG, Zimmet PZ (1998) Definition, diagnosis and classification of diabetes mellitus and its complications. Part 1: diagnosis and classification of diabetes mellitus provisional report of a WHO consultation. Diabet Med 15:539-553

2. Anton B, Fein J, To T, Li X, Silberstein L, Evans CJ (1996) Immunohistochemical localization of ORL-1 in the central nervous system of the rat. J Comp Neurol 368:229-251

3. Bewick GA, Dhillo WS, Darch SJ, Murphy KG, Gardiner JV, Jethwa PH, Kong WM, Ghatei MA, Bloom SR (2005) Hypothalamic cocaine- and amphetamine-regulated transcript (CART) and agouti-related protein (AgRP) neurons coexpress the NOP1 receptor and nociceptin alters CART and AgRP release. Endocrinology 146:3526-3534

4. Filippetti R, Kloting I, Massi M, Cifani C, Polidori C (2007) Involvement of cocaine-amphetamine regulated transcript in the differential feeding responses to nociceptin/orphanin FQ in dark agouti and Wistar Ottawa Karlsburg W rats. Peptides 28:19661973

5. Hunter RG, Philpot K, Vicentic A, Dominguez G, Hubert GW, Kuhar MJ (2004) CART in feeding and obesity. Trends Endocrinol Metab 15:454-459

6. Kloting N, Kloting I (2004) Congenic mapping of type 1 diabetes-protective gene(s) in an interval of $4 \mathrm{Mb}$ on rat chromosome 6q32. Biochem Biophys Res Commun 323:388-394

7. Kristensen P, Judge ME, Thim L, Ribel U, Christjansen KN, Wulff BS, Clausen JT, Jensen PB, Madsen OD, Vrang N, Larsen PJ, Hastrup S (1998) Hypothalamic CART is a new anorectic peptide regulated by leptin. Nature 393:72-76

8. Licht CM, Vreeburg SA, van Reedt Dortland AK, Giltay EJ, Hoogendijk WJ, DeRijk RH, Vogelzangs N, Zitman FG, de Geus EJ, Penninx BW (2010) Increased sympathetic and decreased parasympathetic activity rather than changes in hypothalamicpituitary-adrenal axis activity is associated with metabolic abnormalities. J Clin Endocrinol Metab 95:2458-2466

9. Maolood N, Meister B (2010) Nociceptin/orphanin FQ peptide in hypothalamic neurones associated with the control of feeding behaviour. J Neuroendocrinol 22:75-82

10. Marti M, Viaro R, Guerrini R, Franchi G, Morari M (2009) Nociceptin/orphanin FQ modulates motor behavior and primary motor cortex output through receptors located in substantia nigra reticulata. Neuropsychopharmacology 34:341-355

11. Matsushita H, Ishihara A, Mashiko S, Tanaka T, Kanno T, Iwaasa H, Ohta H, Kanatani A (2009) Chronic intracerebroventricular infusion of nociceptin/orphanin FQ produces body weight gain by affecting both feeding and energy metabolism in mice. Endocrinology 150:2668-2673

12. Mattson MP (2009) Roles of the lipid peroxidation product 4-hydroxynonenal in obesity, the metabolic syndrome, and associated vascular and neurodegenerative disorders. Exp Gerontol 44:625-633

13. Nazzaro C, Marino S, Barbieri M, Siniscalchi A (2009) Inhibition of serotonin outflow by nociceptin/orphaninFQ in dorsal raphe nucleus slices from normal and stressed rats: role of corticotropin releasing factor. Neurochem 54:378-384

14. Neal CR Jr, Mansour A, Reinscheid R, Nothacker HP, Civelli O, Watson SJ Jr (1999) Localization of orphanin FQ (nociceptin) peptide and messenger RNA in the central nervous system of the rat. J Comp Neurol 406:503-547

15. Norton CS, Neal CR, Kumar S, Akil H, Watson SJ (2002) Nociceptin/Orphanin FQ and opioid receptor-like receptor mRNA expression in dopamine systems. J Comp Neurol 444(4):358-368 
16. Osei-Hyiaman D, Depetrillo M, Harvey-White J, Bannon AW, Cravatt BF, Kuhar MJ, Mackie K, Palkovits M, Kunos G (2005) Cocaine- and amphetamine-related transcript is involved in the orexigenic effect of endogenous anandamide. Neuroendocrinology 81:273-282

17. Pietras TA, Rowland NE (2002) Effect of opioid and cannabinoid receptor antagonism on orphanin FQ-induced hyperphagia in rats. Eur J Pharmacol 442:237-239

18. Plagemann A, Harder T, Brunn M, Harder A, Roepke K, fWittrock-Staar M, Ziska T, Schellong K, Rodekamp E, Melchior K, Dudenhausen JW (2009) Hypothalamic proopiomelanocortin promoter methylation becomes altered by early overfeeding: an epigenetic model of obesity and the metabolic syndrome. J Physiol 587:4963-4976

19. Polidori C, de Caro G, Massi M (2000) The hyperphagic effect of nociceptin/orphanin FQ in rats. Peptides 21:1051-1062

20. Przydzial MJ, Garfield AS, Lam DD, Moore SP, Evans ML, Heisler LK (2010) Nutritional state influences Nociceptin/ Orphanin FQ peptide receptor expression in the dorsal raphe nucleus. Behav Brain Res 206:313-317

21. Rodi D, Polidori C, Bregola G, Zucchini S, Simonato M, Massi M (2002) Pro-nociceptin/orphanin FQ and NOP receptor mRNA levels in the forebrain of food deprived rats. Brain Res 957:354361

22. Rogge G, Jones D, Hubert GW, Lin Y, Kuhar MJ (2008) CART peptides: regulators of body weight, reward and other functions. Nat Rev Neurosci 9:747-758

23. Stanley SA, Small CJ, Murphy KG, Rayes E, Abbott CR, Seal LJ, Morgan DG, Sunter D, Dakin CL, Kim MS, Hunter R, Kuhar M, Ghatei MA, Bloom SR (2001) Actions of cocaine- and amphetamine-regulated transcript (CART) peptide on regulation of appetite and hypothalamo-pituitary axes in vitro and in vivo in male rats. Brain Res 893:186-194

24. Straznicky NE, Lambert GW, Lambert EA (2010) Neuroadrenergic dysfunction in obesity: an overview of the effects of weight loss. Curr Opin Lipidol 21:21-30

25. Wang C, Billington CJ, Levine AS, Kotz CM (2000) Effect of CART in the hypothalamic paraventricular nucleus on feeding and uncoupling protein gene expression. Neuroreport 11:32513255

26. Yang SC, Shieh KR, Li HY (2005) Cocaine- and amphetamineregulated transcript in the nucleus accumbens participates in the regulation of feeding behavior in rats. Neuroscience 133:841-851 